Vavrenyuk Sergey Anatolievich,

PhD in Public Administration, Doctoral candidate of Educational, Scientific and Production Center of the National University of Civil Defense of Ukraine, 61023, Kharkiv, Str. Chernyshevska, 94, tel.: (057) 70031 71, e-mail: sergei-vavrenyuk@nuсzи.еdu.uа

ORCID: 0000-0002-6396-9906

Вавренюк Сергій Анатолійович, кандидат наук з державного управління, докторант навчально-науково-виробничого центру Національного університету цивільного захисту України, 61023, Україна, м. Харків, вул. Чернишевська, 94, тел.: (057) 70031 71, e-mail: sergei-vavrenyuk@nuсzu.edu.ua

ORCID: 0000-0002-6396-9906

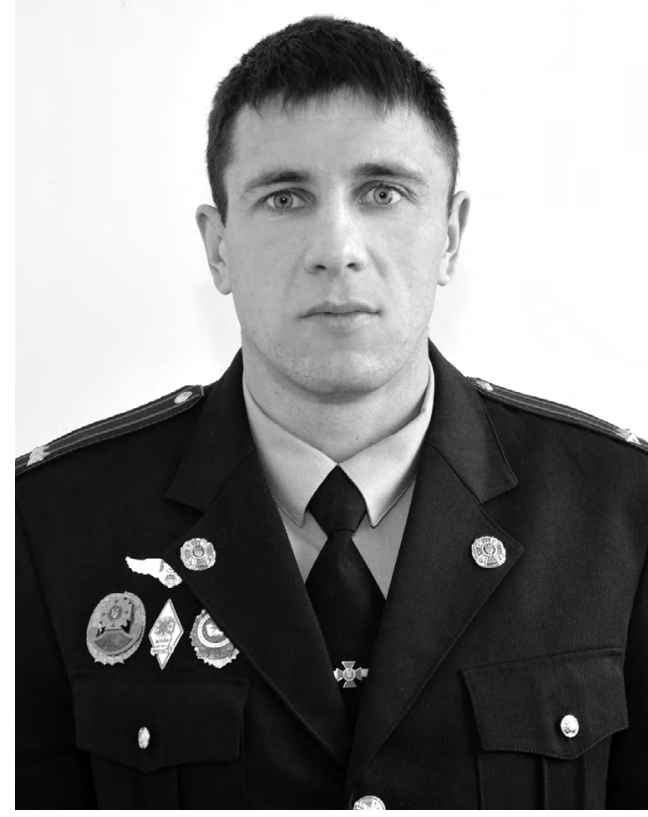

Вавренюк Сергей Анатольевич,

кандидат наук по государственному управлению, докторант учебно-научно-производственного центра Национального университета гражданской защиты Украины, 61023, Украина, г. Харьков, ул. Чернышевская, 94, тел.: (057) 70031 71, е-таil: sergeivavrenyuk@nuczu.edu.ua

\title{
MONITORING AS A MEANS OF ACHIEVING THE QUALITY OF HIGHER EDUCATION IN UKRAINE
}

Abstract. This article is devoted to one of the topical issues in the system of higher education in Ukraine - the achievement of quality education and the provision of educational services by higher education institutions. An important process for achieving quality is monitoring. Therefore, the author presents an analysis of the concept and components of monitoring, which is one of the tools for managing the higher education system both at the macro and micro levels.

The purpose of the article is to find current problems of organizing and monitoring the quality of education in the system of higher education in Ukraine, as well as analysis of the directions of its use.

In the course of the analysis, the author determines that monitoring technologies in the education system have great opportunities, but his direct impact on the effectiveness of the quality of education is not sufficiently taken into account. 
In addition, the author points out the directions for achieving the main limits of the high quality of education in educational institutions through monitoring, which is capable of providing a comprehensive and systematic nature of the study. The types and goals of the training monitoring, organizational and methodological approaches to its implementation, as well as the principles and stages of monitoring were studied in detail.

It is determined that monitoring does not act as a universal tool, but its effective organization, which will meet the existing conditions, and the adequate application of its results give to a significant improvement in the quality of the educational process. The article reveals the relationship between the monitoring of education and the process of managing the higher education system, examines the similarities and differences between the monitoring and control of education and educational institutions.

In conclusion, the author gives solutions to possible problems in the implementation of the monitoring process in assessing the quality of education. At the same time, it points to the need for an integrated assessment, which will help more effective monitoring, thereby improving the quality of education.

Keywords: monitoring, quality of higher education, educational services, higher education.

\section{МОНТТОРИНГ ЯК ЗАСІБ ДОСЯГНЕННЯ ЯКОСТІ ВИЩОЇ ОСВІТИ УКРАЇНИ}

Анотація. Розглянуто систему вищої освіти України: досягнення якості освіти та надання освітніх послуг вищими навчальними закладами. Важливим процесом для досягнення якості є моніторинг. Проаналізовано поняття та компоненти моніторингу як одного з інструментів управління системою вищої освіти на макро- та мікрорівні.

Визначено, що моніторингові технології в системі освіти мають великі можливості, однак недостатньо враховано його безпосередній вплив на ефективність якості освіти.

Окреслено напрями для досягнення основних параметрів високої якості освіти в навчальних закладах за допомогою моніторингу, який здатний забезпечити комплексний та системний характер дослідження. Детально вивчені види і завдання навчального моніторингу, організаційно-методичні підходи до його проведення, а також принципи і етапи.

Визначено, що моніторинг не є універсальним засобом, але його ефективна організація, що відповідатиме існуючим умовам, і адекватне застосування його результатів сприятиме суттєвому підвищенню якості освітнього процесу.

Розкрито зв'язок моніторингу освіти і процесу управління системою вищої освіти, а також схожість і відмінність між процесом моніторингу, контролем освіти і навчальних закладів.

Запропоновано шляхи вирішення можливих проблем при впровадженні процесу моніторингу в оцінку якості освіти. При цьому визначено необхід- 
ність проведення комплексної оцінки, яка буде сприяти більш ефективному проведенню моніторингу, тим самим підвищуючи якість освіти.

Ключові слова: моніторинг, якість вищої освіти, освітні послуги, вища освіта.

\section{МОНИТОРИНГ КАК СРЕДСТВО ДОСТИЖЕНИЯ КАЧЕСТВА ВЫСШЕГО ОБРАЗОВАНИЯ УКРАИНЫ}

Аннотация. Рассмотрена одна из актуальных тем в системе высшего образования Украины - достижение качества образования и предоставление образовательных услуг высшими учебными заведениями. Важным процессом для достижения качества является мониторинг. Проанализированы понятия и компоненты мониторинга одного из инструментов управления системой высшего образования на макро- и микроуровне.

Определено, что мониторинговые технологии в системе образования имеют большие возможности, однако недостаточно учтено его непосредственное влияние на эффективность качества образования.

Очерчены направления для достижения основных параметров высокого качества образования в учебных заведениях с помощью мониторинга, который способен обеспечить комплексный и системный характер исследования. Подробно изучены виды и задачи учебного мониторинга, организационнометодические подходы к его проведению, а так же его принципы и этапы.

Определено, что мониторинг не выступает как универсальное средство, но его эффективная организация, которая будет отвечать существующим условиям, и адекватное применение его результатов способствует существенному повышению качества образовательного процесса.

Раскрыта связь мониторинга образования и процесса управления системой высшего образования, а также сходства и отличия между процессом мониторинга, контролем образования и учебных заведений.

Предложены пути решения возможных проблем при внедрении процесса мониторинга в оценку качества образования. При этом указывается необходимость проведения комплексной оценки, которая будет способствовать более эффективному проведению мониторинга, тем самым повышая качество образования.

Ключевые слова: мониторинг, качество высшего образования, образовательные услуги, высшее образование.

Problem statement. One of the separate issues that is currently insufficiently solved is the creation of a quality management system at a higher education institution, because according to the conditions for the cre- ation of a single European educational space, the educational institution is responsible for the quality of educational services. Particularly urgent is the problem of assessing the quality of the educational process by monitor- 
ing the effectiveness of the educational activities of the institution of higher education. For a modern educational system, the quality problem becomes of the highest relevance. In addition, the quality of education primarily determines the characteristics of the result of study in a higher education institution, fixes changes in the system of professional knowledge and skills of students during the passage of all stages of the educational process, from the initial to the final level of study of the discipline. It should be noted that the quality of education is inextricably linked with the problem of monitoring research.

Analysis of recent publications on research issues. In recent years, considerable attention has been paid to improving the quality of higher education. Thus, G. Shrikanthan and others talk about the need to develop a coherent model of higher education quality [1]. Various aspects that affect the quality of education are considered by E. van Kemenade et al. [2]. Considerable attention is paid to the various processes used to assess the quality of education and monitoring as an instrument for this. J. Lyotard emphasizes that education is an institutionalized, that is, formal, process, on the basis of which society transmits values, skills and knowledge from one person, group, community - to others [3].

If we consider such concepts as "quality of higher education" and "monitoring the quality of education", it should be noted that they did not find their final definition in pedagogical theory and practice. This is evidenced by the results of the theoretical analysis of scientific-pedagogical, methodological, journalistic and information sources of information, where practitioners and theorists do not see a single consensus on the interpretation of "monitoring the quality of education".

In order to reveal the essence of the definition of "monitoring the quality of education", in our opinion, it is necessary to define the concept of "quality of education" in the context of higher education. This moment will establish the relationship between the above concepts and develop a rational and comprehensive system of indicators and criteria in order to determine the quality of higher education as an object of evaluation, since it will reflect all its aspects and components.

Purpose of the article. The purpose of the article is to analyze the concept of monitoring the quality of education, as well as the main methods and directions of using the monitoring process for the development of higher education in Ukraine.

Presenting the main material of research. The quality of educational activities serves as a set of characteristics of the system of higher education and its components, which determines its ability to meet the established and predicted needs of an individual and society as a whole. Today, we see that, together with the formation and development of the European educational space, the issues of the quality of higher education become topical. However, according to some experts, the positions of the European educational space on the issues of ensuring the quality of higher education in the text of the Bologna Declaration are not clearly defined. 
To determine the quality of educational services, and, with this, the work of the quality management system itself at the institution of higher education, conducts monitoring research. Monitoring provides information management. If students conduct evaluation of the organization of the educational process, the activities of teachers, the very fact of monitoring provides management activities. Knowing the results, the teachers adjust their activities in accordance with the criteria for which the evaluation was carried out [4].

That is why, in our opinion, an important point in determining the quality of education in an educational institution is monitoring. This leads to the need to reveal the essence of the concept of "monitoring the quality of higher education."

As a result of the theoretical analysis of scientific and pedagogical sources, it should be noted that there is a sufficient diversity of approaches to the concept of "monitoring the quality of education". Understanding the word "monitoring" has a number of definitions and is used not only in education.

In particular, in the pedagogical literature, synonyms such as "control" and "diagnostics" are used for the word "monitoring". As a result of the analysis we can conclude that it is necessary to distinguish these concepts [5].

A number of scientists consider control as one of the functions of management, which is aimed at three tasks: the detection of deviations of the actual results of management from the predicted, clarification of the reasons for the difference between the goal and results of management and the definition of the content of regulatory activity to reduce the occurrence of deviations. When control is part of the management cycle, it is aimed at organizing the implementation of the work plan and its purpose. As a result, the control is situational in nature and is short in time space. The link between control and microelements of the educational system is monitored when monitoring is related to the functioning of the whole system. Prior to planning and decision making, monitoring is required [6].

It should be noted that monitoring, in our opinion, is a broader concept compared to control, which covers both diagnostic studies and control measurements and analyzes. When diagnosing, we find out all the circumstances of the movement of the educational process and determine its results. And with control, more attention is drawn to the object in a state of stable functioning. Generally are two basic types of control: control results, ie what has been done with the target remaining unfulfilled and what results were obtained, and the control process that helps detect possible abnormal activity and the level of rational activity and its temporal characteristics.

Summarizing the above, we note that monitoring allows for the optimal combination of control and process results. In addition, monitoring involves analysis, diagnosis, regulation, programming, design and problem-solving. Through monitoring, not only the process and its result are studied, but also the project of new activity is being created at the present stage of development of the system of higher education and the possibilities of higher educa- 
tion institutions are considerably expanded.

In fact, monitoring is identified with the system of collecting and analyzing relevant information, while it is important to understand the requirements that are put forward for information. Monitoring provides research that focuses on the main parameters of an educational institution. When conducting monitoring studies it is necessary to store results and accumulate a data bank. However, this can not be done without informational support, therefore the development and application of the information system should be considered as an integral part of the main task of implementing the quality system of higher education institution [7].

The main task of the information system is to support the quality system, to increase the efficiency and effectiveness of its functioning, in order to ensure a high level of satisfaction of all stakeholders in the activities of the institution of higher education. Such a system has a positive effect on the improvement of both educational and financial and economic indicators. The implementation of the information system requires the support of senior management and the relevant resources of the institution of higher education. Today in our country a universal model of the information system for maintaining the quality system of educational institutions is used, it is a three-level system and consists of a documentation management system, database management system and knowledge management system.

In order to maintain a system for monitoring the quality of education, a clear distinction needs to be drawn between responsibilities and powers. The method of developing and implementing monitoring of the quality of education in an educational institution can also be used in organizations for another profile and type of activity, as the organization has a direction for continuous improvement of the kind of activity, providing a systematic approach, stimulating the introduction of innovative technologies and improving the level of satisfaction of educational services consumers.

According to scientists, monitoring is aimed at achieving the main parameters of an educational institution and has the status of research, rather than acting as a means of empirical gathering of materials. It provides a comprehensive, systemic character and creates conditions for planning. In order to conduct monitoring studies, it is necessary to develop a methodology, that is to define the necessary methods and tools, in particular questionnaires, questionnaires, interviews, interviews [8].

Turning to the differences between monitoring and control, it is worth noting that during the monitoring study there is a repetition over a certain period of time and one object is investigated. At the same time, it is necessary to develop a concept that should include the strategic goal, objectives, research objectives and problems with a number of questions and answers that can be obtained through the developed methods. Therefore, it can be argued that monitoring is needed to collect data about a particular research object and is repeated over time.

It should also be noted that the monitoring relationship with the culture of evaluation, the compliance of its 
procedures with the culture of evaluation, as it is an important condition for monitoring effectiveness.

The culture of evaluation can be characterized by the following indicators:

- availability of clear criteria for evaluation;

- development of evaluation procedure;

- the presence of qualified experts;

- clear forms of fixing information during monitoring;

- timing characteristics of the evaluation are developed;

- clear linkage of evaluation with decision making.

During monitoring, there is a continuous or periodic monitoring of the environment in order to prevent unwanted deviations from the main parameters under study. Monitoring is systematic in nature and preventive.

Under educational monitoring, we can understand the system of collecting, preserving, processing and disseminating information about the activity of the pedagogical system, which ensures continuous monitoring of its condition and development forecasting. Speaking about monitoring in the education system, it should be noted that this is aimed at organized, targeted, systematic monitoring of the quality of education, which allows to detect deviations from the state standards and the level of satisfaction of educational needs of the population [9].

In our view, monitoring of the quality of higher education involves regular, specially organized systematic monitoring of the quality of higher education, that is, educational services provided by higher education institutions, as well as activities of quality management systems in this higher education institution.

After the theoretical analysis of scientific and pedagogical sources of information, one can determine the following monitoring functions, such as: diagnostic, informational, analytical, evaluation, stimulating, motivational, controlling, prognostic, corrective.

Depending on the monitoring procedures, the type of monitoring determined by the tasks, goals, various procedures and semantic features is determined.

Yes, you can distinguish the following types of monitoring:

- Strategic, tactical and operational, in accordance with the scale of the goals and objectives of the educational affairs;

- entrance or selective, educational or variable, outgoing or final, depending on the stages of training;

- retrospective, precautionary, fluid, compared with the time scale;

- one-time, periodic, systematic, according to the frequency of procedures;

- local, selective, continuous, taking into account the scale of the object of observation;

- Individual, group, frontal, depending on organizational forms;

- external or social, mutual control, self-examination, if involved analytical procedures in the context of subjectobjective relations;

- standard, non-standard, matrix, when applied tools;

- local, modular, systemic, during large-scale innovation.

It should be noted that the purpose of monitoring is to improve the efficiency of the system, especially the 
efficiency of the institution of higher education, due to the improvement of the quality of educational services provided by the institution.

Accordingly, educational monitoring is the following: tracking the dynamics of the quality of educational services and monitoring the effectiveness of quality management of education in an educational institution. Depending on this goal, the following tasks can be formulated:

- permanent supervision of the state of higher education and receipt of operational information about it;

- timely detection of changes and deviations that can be taken into account in the system of higher education and the factors causing these changes;

- prevention of negative trends;

- realization of forecasting of development of the basic processes at the institution of higher education;

- assessment of the completeness and effectiveness of the implementation of methodological provision of education.

The basic principles of educational monitoring should include: the principle of scientific, professional compliance, continuity, integrity. And in order to carry out educational monitoring it is necessary to observe general and organizational-methodical requirements. Thus, among the general requirements distinguish systematic, objectivity, accuracy, sufficiency, completeness, reliability, optimality, structuring, generalization, efficiency, accessibility, accounting psychological and pedagogical peculiarities, humanistic orientation [10].

If you apply organizational and methodological requirements for moni- toring, you need to pay attention to the following:

- monitoring should be carried out with a limited and constant set and a form of indicators during the established period;

- Indicators should capture the phenomena of the educational process, which are already sufficiently studied scientifically and can adequately reflect the quality of education;

- Indicators should be of assessment nature;

- at least once a year you need to adjust the set of indicators that are used;

- the results of monitoring do not allow repressive measures, but only the nature of incentives for teachers in their professional activities.

Regarding the monitoring approach, it should be noted that there is no single approach to the number and names of its stages. In the pedagogical literature the following stages are defined:

- preparatory, that is, finding out the purpose, determining the object, setting the time of observation, interviewing, testing, questioning, observation, control of diagnostic sections;

- Analytical, which includes the analysis and systematization of information received, the development of recommendations and proposals for the next period, the formation of conclusions.

A number of other scientists distinguish the following stages of the monitoring process:

- normatively-established, during which determines the purpose and tasks of pedagogical monitoring, the main indicators and criteria, means of achieving real indicators of the research object; 
- analytical, which includes the collection of information using selected methods, quantitative and qualitative processing of the results, development of pedagogical diagnosis;

- Diagnostic, which includes an analysis of the results of the work performed, the definition of the real level of achievements of the monitoring object, its comparison with the normative indicators, information about the results of the organization and monitoring;

- prognostic, predicts further trends and opportunities for the development of the object under study, development of a plan for pedagogical corrective actions;

- active-technological, which carries out the correction of the pedagogical process.

In our opinion, it is precisely these stages of monitoring that clearly describe the procedure for monitoring.

Conclusions and prospects for further research. Summarizing the above, one should say that the quality of education, and especially higher education, arose in connection with the accession of our state to the European educational area. It has become known that the definition of the quality of higher education is linked to special procedures, the creation of new institutions, the purpose of which should be a public assessment of the quality of educational services to be provided. At each educational level - a national, regional, higher education institution level, systematic and systematic study of the quality of educational activities is required.

Thus, during the analysis of theoretical material it was established that today there is no single approach to defining the definition of "monitoring the quality of education". To implement the monitoring tasks, it is necessary to develop scientific and practical tools. The most rational methods for solving such problems are survey method, expert evaluation, observation, studying of documentation.

Among the indicators of the quality of education can be identified university level, institute (faculty) level and indicators of the quality of education at the cathedral level. The structuring of the work of higher education institutions and the effectiveness of the management system should form the basis for assessing the quality of the institution's work in general. Assessment of the quality of the educational process should determine the quality of the curriculum, plans, schedule of classes, the composition of scientific and pedagogical workers and students.

In assessing the quality of research activities, it is necessary to pay attention to the assessment of the qualitative composition of research workers, the qualitative use of funds allocated for research.

In order to determine the comprehensive assessment of the quality of educational services, it is necessary to take into account the opinion of three parties: students, young graduates and employers who will be direct managers. The result of the integrated assessment will be the calculation of the integral indicator, that is, the level of quality of educational services, which will be calculated as the root of the third stage of the three indicators, which reflect the independent assessment of the direct consumers of specific products. 


\section{REFERENCES}

1. Srikanthan G., Dalrymple J. F. (2002). Developing a holistic model for quality in higher education. Quality in Higher Education. Vol. 8 (3). pp. 215224.

2. Van Kemenade E., Pupius M., Hardjono $T$. W. (2008). More value to defining quality. Quality in Higher Education. Vol. 14 (2). Pp. 175-185.

3. Lyotard J., Bennington G. (1984). The postmodern condition: A report on knowledge. Minneapolis: University of Minnesota Press.

4. Khilchenko L. N. (2014). Vnutrennyaya sistema ocenki kachestva obrazovaniya $\mathrm{v}$ universitete - veyanie vremeni ili ostraya neobhodimost [The internal system for assessing the quality of education at the university: the trend of time or the urgent need?]. Modern scientific research and innovations. 11-3 (43). pp. 131-136.

5. Burkina N. S., Lukina T. O. (2001). Monitoring u sistemi zagalnoosvitnoyi pidgotovki [Monitoring in the system of general education]. Education of Ukraine. 8. pp. 5-9.

6. Vavrenyuk S. A. (2018). Pidhodi ta innovacijni tehnologiyi $\mathrm{v}$ osvitnomu prostori [Approaches and innovative technologies in the educational space], Collection of materials of the XIV International Conference "Quality Strategy in Industry and Education”, June 4-7, 2018. Varna, Bulgaria. pp. $151-154$.

7. Albert Tajjman and T. Neville Postwine (2003). Monitoring standartiv osviti [Monitoring of Educational Standards]. Lviv: Litopis, Ukraine.

8. Lokshina O. I. (2004). Monitoring yakosti osviti: svitovi dosyagnennya ta ukrayinski perspektivi [Monitoring the quality of education: world achievements and Ukrainian perspectives], Kyiv, Ukraine.
9. Vavrenyuk, S. (2018). Gosudarstvennoe regulirovanie reformirovaniya vysshego obrazovaniya Ukrainy na sovremennom etape [State regulation of the reform of higher education in Ukraine at the present stage]. Est journal of security studies: Sciences. Journal. Vip. 2 (12). pp. 15-24.

10. Dombrozskaya S. N. (2011). Yakist osviti yak odna z zaporuk vdalogo derzhavnogo reformuvannya vishoyi shkoli Ukrayini [The quality of education as one of the pillars of a successful state reform of higher education in Ukraine]. Actual problems of public administration. 1. pp. 149-154.

\section{СПИСОК ВИКОРИСТАНИХ ДЖЕРЕЛ}

1. Srikanthan G., Dalrymple J. F. Developing a holistic model for quality in higher education / Quality in Higher Education, 2002. Vol. 8 (3). Pp. 215-224.

2. Van Kemenade E., Pupius M., Hardjono $T$. W. More value to defining quality // Quality in Higher Education, 2008. Vol. 14 (2). Pp. 175-185.

3. Lyotard J., Bennington G. The postmodern condition: A report on knowledge. Minneapolis: University of Minnesota Press, 1984. 108 p.

4. Хильченко Л. Н. Внутренняя система оценки качества образования в университете: веяние времени или острая необходимость? // Современные научные исследования и инновации. 2014. № 11-3 (43). C. 131-136.

5. Буркіна Н. С., Лукіна Т. О. Моніторинг у системі загальноосвітньої підготовки // Освіта України. 2001. № 8. C. 5.

6. Вавренюк С. А. Підходи та інноваційні технології в освітньому просторі / С. А. Вавренюк // Збірник матеріалів XIV Міжнародної конференції 
“Стратегія якості у промисловості і освіті”, 4-7 червня 2018 р., Варна, Болгарія. С. 151-154.

7. Моніторинг стандартів освіти / За ред. Альберта Тайджмана і Т. Невілла Послтвейна. Львів: Літопис, 2003. - 328 c.

8. Моніторинг якості освіти: світові досягнення та українські перспективи / За заг. ред. О. І. Локшиної. K.: K.I.C., 2004. 128 c.

9. Вавренюк C. А. Государственное регулирование реформирования выс- шего образования Украины на современном этапе / С. А. Вавренюк // EAST JOURNAL OF SECURITY STUDIES vol. 2/2, Науковий журнал "Східний часопис безпекових студій”, 2018. С. 15-24.

10. Домбровська С. М. Якість освіти як одна 3 запорук вдалого державного реформування вищої школи України / С. М. Домбровська // Актуальні проблеми державного управління. 2011. № 1. С. 149154. 

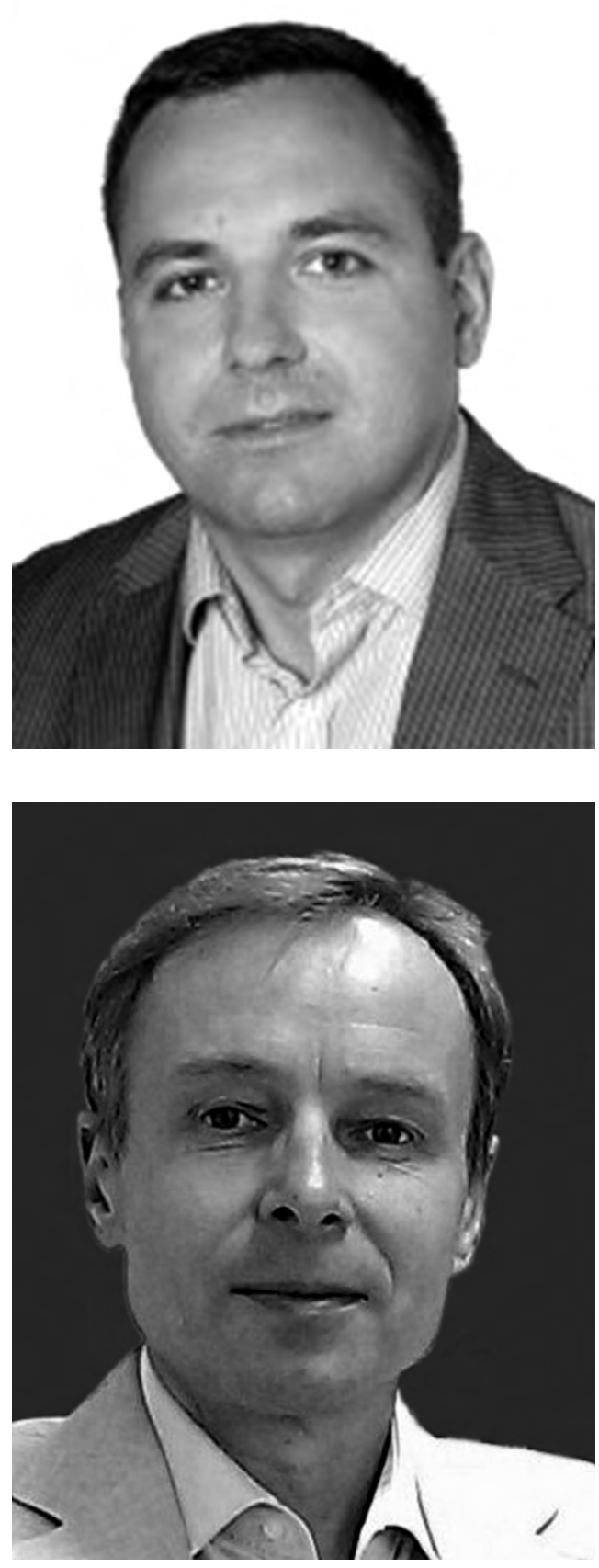

\section{UDC: $316.77: 355.43$}

\section{Gurkovskii Volodymyr Igorevich,}

Doctor of Sciences in Public Administration, Senior Researcher, First Deputy Director of the Center for Research in Public Administration Problems, 03057, Kyiv, Str. Antona Tsedika st., 20, tel: (067) 50269 00, e-mail: vladimir.gurkovskyi@gmail.com.

ORCID: 0000-0003-2021-5204

\section{Гурковський Володимир Ігорович,} доктор наук з державного управління, старший дослідник, перший заступник директора ВГО “Центр досліджень проблем публічного управління”, 03057, м. Київ, вул. Антона Цедіка, 20, тел: (067) 50269 00, e-mail: vladimir. gurkovskyi@gmail.com.

ORCID: 0000-0003-2021-5204

\section{Гурковский Владимир Игоревич,}

доктор наук по государственному управлению, старший исследователь, первый заместитель директора ВОО “Центр исследований проблем публичного управления”, 03057, г. Киев, ул. Антона Цедика, 20, тел: (067) 50269 00, e-mail: vladimir. gurkovskyi@gmail.com.

ORCID: 0000-0003-2021-5204

\section{Solozyov Serhiy Hrigorozych,}

Ph.D. in Social Communications, Associate Professor, Doctorate in the Department of Information Policy and Digital Technologies, National Academy of Public Administration under the President of Ukraine, 03057, Kyiv, Str. Antona Tsedika 20, tel: (050) 98464 01, e-mail: solovyov.post@ gmail.com

ORCID: 0000-0002-6266-0747

\section{Соловйов Сергій Григорович,}

кандидат наук із соціальних комунікацій, доцент, докторант кафедри інформаційної політики та цифрових технологій, Національна академія державного управління при Президентові Украӥни, 03057, м. Київ, вул. Антона Цедіка, 20, тел: (050) 98464 01, e-mail: solovyoz.post@gmail.com

ORCID: 0000-0002-6266-0747 